\title{
Opiate-Receptor Blockade Reduces Voluntary Running but Not Self-Stimulation in Hamsters
}

\author{
CAREN D. POTTER, ${ }^{1}$ KATARINA T. BORER \\ Department of Physical Education, The University of Michigan, Ann Arbor, MI 48109 \\ AND \\ RICHARD J. KATZ \\ Department of Psychology, Johns Hopkins University, Baltimore, MD 21218
}

Received 18 May 1982

\begin{abstract}
POTTER, C. D., K. T. BORER AND R. J. KATZ. Opiate-receptor blockade reduces voluntary running but not selfstimulation in hamsters. PHARMACOL BIOCHEM BEHAV 18(2) 217-223, 1183.-Naltrexone HCl, a long-acting opiate receptor blocker was administered to female hamsters at two doses, 10 and $20 \mathrm{mg} / \mathrm{kg}$, IP prior to $12 \mathrm{hr}$ of nocturnal running or every $12 \mathrm{hr}$ during access to hypothalamic self-stimulation to determine whether endogenous opiates played a role in either of these two motivated behaviors. Naltrexone suppressed total running activity and speed, and caused an increase in pause time but did not affect the rate of hypothalamic self-stimulation. Furthermore, weight gain was unaffected by four weeks of self-stimulation but was accelerated during two weeks of voluntary running. Thus stimulation of endogenous opiate receptors helps support high levels of voluntary running but is not involved in initiation of running or in maintenance of intracranial self-stimulation in female hamsters. Furthermore, the association of opiate receptor stimulation and increased somatic growth with voluntary running but not with self-stimulation suggests a possible facilitatory role for endogenous opiates in acceleration of growth by exercise.
\end{abstract}

Opiate receptors Hamsters Running Self-stimulation Naltrexone

PHYSICAL activity is accompanied by the release of endogenous opiates into the blood stream $[2,10,12,14,16,39]$ and within the brain [39]. The significance of these changes is not fully understood, but at least four roles for exerciseinduced opiate release have been hypothesized. First, exercise is interpreted by many to be a non-specific stressor. Opiate release during physical activity may reduce discomfort in a manner similar to that seen in other situations evoking stress-induced analgesia $[11,25,41]$. Secondly, opiates may be involved in the activation of physical activity. Low intraventricular doses of opioid peptides enhanced grooming in rats [18] while central injections of enkephalin analogues increased exploratory behavior [24] and motor activity [23] in mice. Conversely, administration of an opiate antagonist lowered open-field activity in rats [38]. Thirdly, endogenous opiates may be acting as reward transmitters for the reinforcing aspects of physical activity. Reports of trance-like states in long distance runners [31], and intrinsic rewards of running, such as "sheer joy" [28] suggest that physical activity may have opiate-like reinforcing properties [1,33]. Finally, endogenous opiates may be involved in some of the neuroendocrine phenomena associated with prolonged phys- ical activity. For example, enhanced opiate release in women participating in an exercise program [10] may be related to the delayed onset of puberty [17, 26, 40] and amenorrhea $[13,15,27]$ seen in some women athletes. The pattern of circulating gonadotropin release is altered during the follicular phase of the menstrual cycle in some women athletes [3]: opiates are also known to suppress gonadotropin release $[9,34]$. In addition, physical activity facilitates growth hormone $(\mathrm{GH})$ release in animals [6] and in man [35], while opiates are also known to facilitate $\mathrm{GH}$ and prolactin (PRL) release $[9,32,37]$.

To extend our understanding of the biological roles of endogenous opiates in prolonged submaximal physical activity, we examined the effect of naltrexone, a long-acting opiate receptor blocking agent, on spontaneous running in golden hamsters. Spontaneous running in these animals has characteristics analogous to those of long-distance running in man. Running bouts are initiated voluntarily by hamsters and separated by brief pauses. Young adult hamsters run between 11 and 16 kilometers a night [4]. The number of running bouts initiated each night with and without the administration of the opiate antagonist shed light on the role of en-

'Requests for reprints should be addressed to Caren D. Potter, Department of Physical Education, The University of Michigan, 401 Washtenaw Avenue, Ann Arbor, MI 48109. 
dogenous opiates in initiating activity. On the other hand, analysis of the amount of running activity and the duration and speed of running bouts allows us to investigate the role of endogenous opiates in response maintenance through effects on the reinforcing properties of running [4,5]. Finally, we compared the effects of opiate receptor blockade on spontaneous running and hypothalamic self-stimulation in the same hamsters to control against a possible general behavioral sedation by the drug and to determine whether opiate involvement is common to these two types of incentive behavior. In the last experiment, we compared changes in ponderal growth during two weeks of running and four weeks of intracranial self-stimulation to see whether facilitation of somatic growth and endogenous opiate release were common to both of these motivated behaviors.

\section{METHOD}

\section{Animals and Maintenance}

Female golden hamsters (Mesocricetus auratus, Waterhouse) were obtained from Engle Laboratory Animals, Farmersburg, IN, at body weights of about $100 \mathrm{~g}$ and age of about 10 weeks. Animals were maintained with Purina Formulab Chow 5008 and water ad lib in rooms with controlled temperature $\left(20-22^{\circ} \mathrm{C}\right)$ and light $(12 \mathrm{~L}: 12 \mathrm{D})$.

\section{Drug Administration}

All hamsters received IP injections of isotonic saline or one of two doses of naltrexone $\mathrm{HCl}$ (Endo Laboratories. Wilmington, DE) in random order once a day, approximately 20 minutes before the onset of darkness (Experiment 2) or twice a day, before the onset of darkness and before the onset of light (Experiment 1). Naltrexone doses of 10 and 20 $\mathrm{mg} / \mathrm{kg} / 12 \mathrm{hr}$ were previously shown to maintain a physiologically effective chronic blockade of opiate receptors in rodents $[21,29,36]$.

\section{Electrode Implantation}

Ten adult female hamsters anesthetized with sodium pentobarbital $(75 \mathrm{mg} / \mathrm{kg}$, IP) had stainless steel stimulation electrodes implanted in lateral hypothalamic sites found previously to support intracranial self-stimulation [8]. A Kopf stereotaxic instrument held the skull horizontal between bregma and lambda. The electrodes were insulated with Epoxylite except for $0.5 \mathrm{~mm}$ at the tip. A $1 \mathrm{~cm}$-long copper brush at the distal end of the electrode was permanently mounted on the skull with two screws and further secured with dental cement [21].

Experiment 1: Effects of Opiate Blockade on SelfStimulation and Effect of Self-Stimulation on Weight Gain in Hamsters

The hamsters were housed in suspended wire cages with metal ceilings. The floor served as the stimulation ground. When the metal brush on the animal's head came in contact with the ceiling, closure of the circuit allowed delivery of electrical stimulation through the head-mounted brushing. Stimulation consisted of a 0.3 second train of $60 \mathrm{~Hz}$ sinusoidal current between 25 and $50 \mu \mathrm{A}$ in intensity as measured on an oscilloscope. Determination of the current intensity that would sustain self-stimulation behavior occurred during the first 21 days of exposure to the cages. An initial current of $50 \mu \mathrm{A}$ was selected based on previous findings [22]. The current intensity was increased or decreased until the rate of response was stable. After this initial period the hamsters were given four weeks of continuous exposure to selfstimulation. Body weights were recorded daily. During these four weeks. one of the two doses of naltrexone or saline was given to each animal in a randomized order for four consecutive days (Monday-Thursday). Self-stimulation rates were recorded on these days. In addition, self-stimulation rates over a four day no-drug period were also recorded for each animal.

Experiment 2: Effects of Opiate Blockade on Amount and Pattern of Voluntary Running in Hansters

Five of the animals used in Experiment 1 were given two weeks of orientation to cages containing freely turning horizontal running dises [4]. Wheel turns were recorded on electromechanical counters and on Harvard cumulative event recorders. The running patterns were determined in the following manner. Paper speed was $5 \mathrm{~mm} / \mathrm{min}$. A disc turn induced a $0.25-\mathrm{mm}$ sideway pen excursion. Running bouts were defined as episodes of activity consisting of 20 disc revolutions or more, separated by pauses, defined as inactive periods of 150 seconds or longer. Running speed, in revolutions per minute ( $R P M)$, was calculated from the rate of sideway pen excursion within individual running bouts. Total activity, in revolutions per day (RPD), was the total number of revolutions during the 12 hour period of darkness.

After orientation, the hamsters had 2 weeks of continuous exposure to the running discs. During this time weight changes and running pattern were recorded as a function of saline injection $(1 \mathrm{ml} / \mathrm{kg}$, IP), and injection of $10 \mathrm{mg} / \mathrm{kg}$ naltrexone, and $20 \mathrm{mg} / \mathrm{kg}$ naltrexone. IP. At least 24 hours were allowed to elapse between drug or saline injections. Each condition was tested twice and mean values were used in data analysis.

\section{Statistical Analvsis of the Data}

In both experiments the rate of ponderal growth was inferred from a least-squares linear regression analysis of weight changes during the experimental condition. Analysis of covariance and a test for unequal regression coefficients was used to compare the growth rates duripg the two experiments.

In Experiment 1, self-stimulation rates on days of drug administration are expressed as a percentage of selfstimulation rates during the time prior to drug treatment. Hotelling's T Square Test was used on the raw data to compare drug trials and baseline self-stimulation rates.

In Experiment 2, analysis of variance and Scheffe's post-hoc test for multiple comparisons was used to determine the effect of drug treatment on running. Analyses of the effects of opiate blockade on running were done on the entire 12 hour dark period, and on the first 6 hours only, when the effectiveness of the antagonist drug was expected to be maximal.

\section{Histology}

Brains, from animals perfused with saline and $10 \%$ Formalin were fixed in $10 \%$ buffered Formalin for 2-4 days. They were sectioned at $80 \mu \mathrm{m}$ in the coronal plane. Sections were stained with cresyl violet and were projected onto diagrams of a brain from a $100 \mathrm{~g}$ female hamster to determine the location of the electrode tip [7]. Diagrams were drawn in 
TABLE 1

EFFECT OF NALTREXONE ( $10 \mathrm{mg} / \mathrm{kg} / 12 \mathrm{HR})$ ON HYPOTHALAMIC SELF-STIMULATION

\begin{tabular}{|c|c|c|c|c|c|}
\hline \multirow[b]{2}{*}{ Animal } & \multirow{2}{*}{$\begin{array}{c}\text { Pre-Treatment } \\
\text { Self-Stimulation } \\
\text { Rate } \\
\text { (Responses/Day) }\end{array}$} & \multicolumn{4}{|c|}{$\begin{array}{l}\text { Self-Stimulation after } 10 \mathrm{mg} / \mathrm{kg} / 12 \mathrm{hr} \text { Naltrexone } \mathrm{HCl} \\
\text { (Percentage of Pre-Treatment Rate) }\end{array}$} \\
\hline & & Day 1 & Day 2 & Day 3 & Day 4 \\
\hline 1 & 11,010 & 65 & 110 & 54 & 119 \\
\hline 2 & 2,760 & 90 & 105 & 132 & 120 \\
\hline 3 & 4,500 & 123 & 150 & 242 & 25 \\
\hline 4 & 17,400 & 87 & 141 & 40 & 90 \\
\hline \multirow[t]{2}{*}{5} & 1,710 & 104 & 90 & 54 & 87 \\
\hline & Mean \pm S.E.M. & $94 \pm 9.6$ & $119 \pm 11.3$ & $104 \pm 38$ & $88 \pm 17$ \\
\hline
\end{tabular}

TABLE 2

EFFECT OF NALTREXONE (20 mg/kg/12 HR) ON HYPOTHALAMIC SELF-STIMULATION

Self-Stimulation after $20 \mathrm{mg} / \mathrm{kg} / 12 \mathrm{hr}$ Naltrexone $\mathrm{HCl}$ (Percentage of Pre-Treatment Rate)

Pre-Treatment

Self-Stimulation

\begin{tabular}{lcrrrr} 
Animal & $\begin{array}{c}\text { Self-Stimulation } \\
\text { Rate } \\
\text { (Responses/Day) }\end{array}$ & Day 1 & Day 2 & Day 3 & Day 4 \\
\hline 1 & 10,770 & 125 & 196 & 180 & 93 \\
2 & 3,030 & 102 & 87 & 48 & 88 \\
3 & 4,290 & 85 & 166 & 113 & 70 \\
4 & 11,100 & 74 & 121 & 112 & 111 \\
5 & 1,200 & 101 & 143 & 91 & 69
\end{tabular}

Mean \pm S.E.M. $\quad 97 \pm 8.7 \quad 143 \pm 18.7 \quad 109 \pm 21.3 \quad 86 \pm 7.8$

India ink over histological features discernible in photographic prints of sections of this hamster brain in planes ranging between $2 \mathrm{~mm}$ anterior to $2 \mathrm{~mm}$ posterior to bregma.

\section{RESULTS}

Experiment 1: Effects of Opiate Blockade on SelfStimulation and Effects of Self-Stimulation on Weight Gain in Hamsters

The rate of self-stimulation was unaffected by either dose of naltrexone (Tables 1 and 2) when the rate of response on the days of drug administration was compared to pretreatment response rates. Four weeks of self-stimulation had no effect on the rate of weight gain in these animals (Fig. 1).

Experiment 2: Effects of Opiate Blockade on Amount and Pattern of Voluntary Running in Hamsters

The lower dose of naltrexone $(10 \mathrm{mg} / \mathrm{kg}, \mathrm{HCl})$ had no effect on the amount or pattern of voluntary running. However, the higher dose $(20 \mathrm{mg} / \mathrm{kg}, \mathrm{HCl})$ caused an overall inhibition of voluntary running in hamsters. During the first six hours of the dark period (Table 3), total running activity (disk revolutions) was significantly lower following this dose of naltrexone than under control conditions. In addition, run-

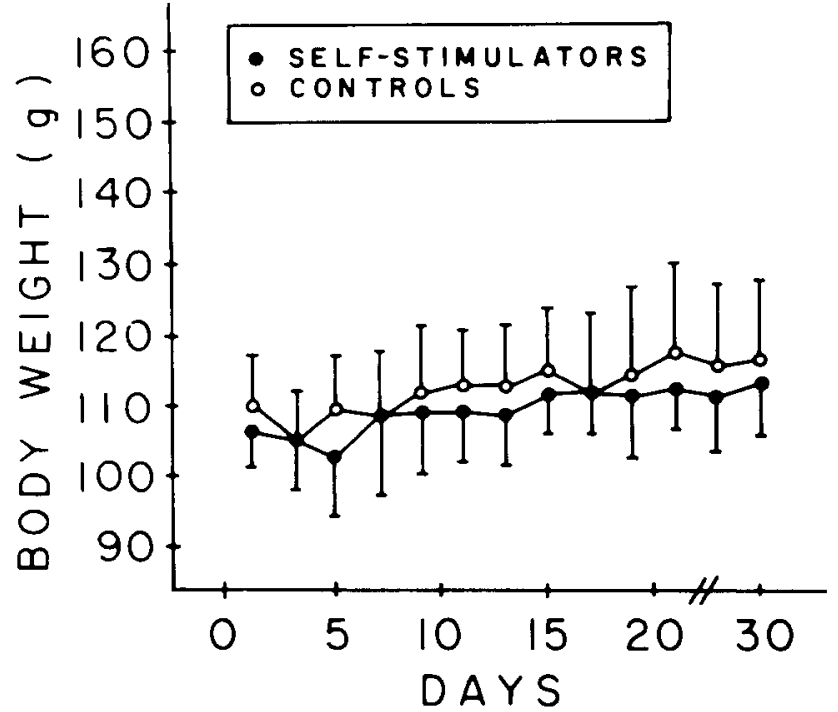

FIG. 1. Weight change of self-stimulating $(n=5$, solid circles) and control hamsters ( $n=5$, open circles). The regressions of the weight change as a function of time are $y=0.27 x+105.2$ for self-stimulating hamsters and $y=0.31 x+107.9$ for the controls. Brackets denote standard errors of the mean. 
TABLE 3

EFFECT OF NALTREXONE ON RUNNING PARAMETERS OVER THE FIRST 6 HOURS OF ACTIVITY PERIOD

\begin{tabular}{|c|c|c|c|c|c|}
\hline & \multirow{2}{*}{$\begin{array}{l}\text { Condition } 1 \\
\text { Control }\end{array}$} & \multirow{2}{*}{$\begin{array}{l}\text { Condition } 2 \\
\text { Naltrexone } \\
10 \mathrm{mg} / \mathrm{kg}\end{array}$} & \multirow{2}{*}{$\begin{array}{c}\text { Condition } 3 \\
\text { Naltrexone } \\
20 \mathrm{mg} / \mathrm{kg}\end{array}$} & \multicolumn{2}{|c|}{$\begin{array}{c}\text { Condition Comparisons } \\
\text { F-Statistic }{ }^{*}\end{array}$} \\
\hline & & & & Condition 1,2 & Condition 1,3 \\
\hline $\begin{array}{l}\text { Total Activity } \\
\text { (Revolutions per Day) }\end{array}$ & $16.733 \pm 881$ & $13,178+2.789$ & $10,594 \pm 711$ & 2.86 & 8.45 \\
\hline Number of Running Bouts & $7 \pm 0.8$ & $4.8 \pm 0.7$ & $9.0 \pm 0.7$ & 3.79 & 2.53 \\
\hline $\begin{array}{l}\text { Duration of Individual } \\
\text { Running Bouts (min) }\end{array}$ & $45.6 \pm 6.1$ & $50.9 \pm 9$ & $26.4 \pm 3.7$ & 0.34 & 4.5 \\
\hline Total Pause Time (min) & $33.8 \pm 4.9$ & $57.9 \pm 21.5$ & $95.0 \pm 26.7$ & 1.24 & 8.04 \\
\hline $\begin{array}{l}\text { Duration of Individual } \\
\text { Pauses (min) }\end{array}$ & $5.6 \pm 0.8$ & $20.4 \pm 11.8$ & $11.3 \pm 2.3$ & 3.31 & 0.49 \\
\hline Speed (RPM) & $50.6 \pm 2.7$ & $\begin{array}{c}48.3 \pm 4.6 \\
\text { Mean } \pm \text { S.E.M. }\end{array}$ & $42.9 \pm 1.3$ & 0.55 & 5.23 \\
\hline
\end{tabular}

${ }^{*} \mathrm{~F}(1,8)=5.23, p<0.05$

TABLE 4

EFFECT OF NALTREXONE ON RUNNING PARAMETERS OVER A 12 HOUR ACTIVITY PERIOD

\begin{tabular}{|c|c|c|c|c|c|}
\hline & \multirow{2}{*}{$\begin{array}{l}\text { Condition } 1 \\
\text { Control }\end{array}$} & \multirow{2}{*}{$\begin{array}{c}\text { Condition } 2 \\
\text { Naltrexone } \mathrm{HCl} \\
10 \mathrm{mg} / \mathrm{kg}\end{array}$} & \multirow{2}{*}{$\begin{array}{c}\text { Condition } 3 \\
\text { Naltrexone } \mathrm{HCl} \\
20 \mathrm{mg} / \mathrm{kg}\end{array}$} & \multicolumn{2}{|c|}{$\begin{array}{c}\text { Condition Comparisons } \\
\text { F-Statistic* }\end{array}$} \\
\hline & & & & Condition 1,2 & Condition 1,3 \\
\hline $\begin{array}{l}\text { Total Activity } \\
\text { (Revolutions per Day) }\end{array}$ & $23,578 \pm 2,609$ & $23,386 \pm 2,728$ & $15,982 \pm 2,107$ & 0.006 & 8.76 \\
\hline Number of Running Bouts & $10 \pm 0.88$ & $8.8 \pm 0.7$ & $14 \pm 1.6$ & 0.4739 & 5.26 \\
\hline $\begin{array}{l}\text { Duration of Individual } \\
\text { Running Bouts (min) }\end{array}$ & $40.7 \pm 4.4$ & $46.2 \pm 2.4$ & $25 \pm 3.5$ & 1.23 & 10.02 \\
\hline Total Pause Time (min) & $142.3 \pm 19.7$ & $183.6 \pm 36.6$ & $279.1 \pm 64.3$ & 0.659 & 7.22 \\
\hline $\begin{array}{l}\text { Duration of Individual } \\
\text { Pauses (min) }\end{array}$ & $17.4 \pm 3.1$ & $24.8 \pm 5.2$ & $23.8 \pm 8.1$ & 1.06 & 0.793 \\
\hline Speed (RPM) & $52.7 \pm 1.8$ & $\begin{array}{c}52.8 \pm 2.7 \\
\text { Mean } \pm \text { S.E.M. }\end{array}$ & $43.6 \pm 2.6$ & 0.008 & 11.3 \\
\hline
\end{tabular}

${ }^{*} \mathrm{~F}(1.8)=5.23, p<0.05$.

ning speed was significantly slower and total pause time was significantly longer. When the entire 12 hour period of darkness is considered (Table 4), the significant effects of the higher dose of naltrexone were; reduction in total running activity (disk revolutions), a slower running speed, and a decrease in the duration of the individual running bouts. Also, total pause time was longer and more running bouts were initiated.

The rate of weight gain in the five hamsters was significantly higher during the two weeks of voluntary running $(1.1 \pm 0.1 \mathrm{~g} /$ day $)$ than during the four weeks of intracranial self-stimulation $(0.4 \pm 0.1 \mathrm{~g} /$ day, Fig. 2$)$.

Histological examination of electrode placement was available for all but 2 animals whose brains were inadequately preserved. Effective sites which sustained stable rates of intracranial self-stimulation were in the area of medial forebrain bundle (MFB) between the optic chiasms and the median eminence. Ineffective placements in control animals were generally anterior, dorsal or posterior to the MFB sites (Fig. 3).

\section{DISCUSSION}

Our experiments indicate that the endogenous opiates play a facilatory role in the maintenance of voluntary running in female hamsters.

Administration of naltrexone, a long-acting opiate receptor blocker, had an inhibitory influence on the total amount of voluntary running in hamsters. Suppression of running speed and the duration of individual running bouts resulted in fewer disk revolutions and longer pauses. The hamsters initiated more running bouts under the influence of the higher dose of naltrexone than under control conditions, but this increase in running bouts could not counteract the overall inhibitory influence of naltrexone on running.

Since, at the same dose, naltrexone had no effect on the amounts of intracranial self-stimulation, naltrexone did not appear to induce generalized behavioral inhibition or debilitation. The specificity of drug effects on voluntary running, and the nature of changes in the pattern of running behaviors makes us conclude that naltrexone has altered the incentive 


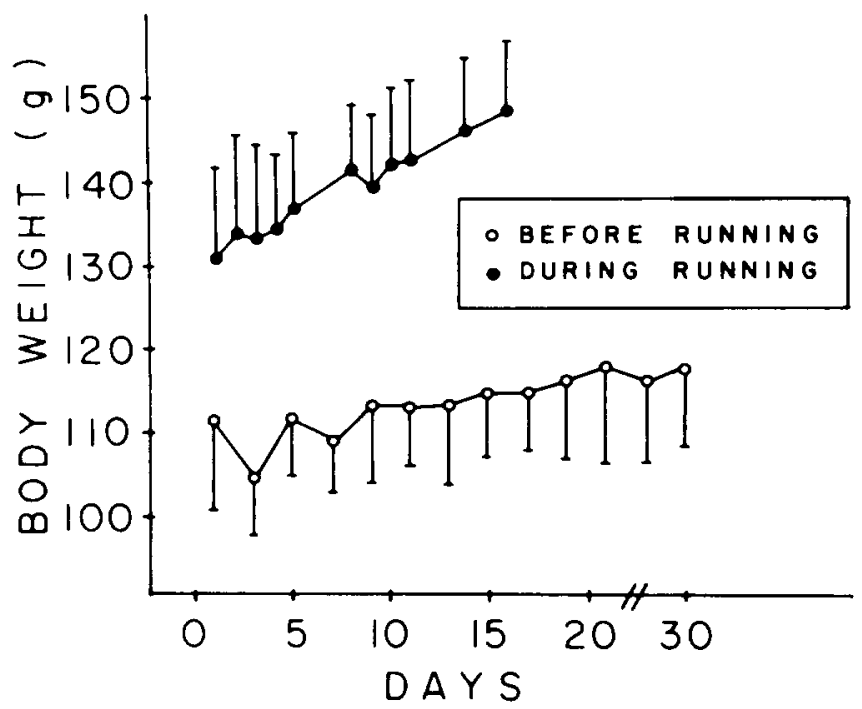

FIG. 2. Weight change of the five hamsters during four weeks of intracranial self-stimulation (bottom) and two weeks of voluntary running (top). The regressions of the weight change as a function of time are $y=0.35 x+108.6$ during the exposure to self-stimulation and $y=1.13 x+130.5$ during voluntary running. Brackets denote standard errors of the mean.

properties of voluritary running. We base this inference on the data from other experiments which suggest that total amount of voluntary running, speed of running, and duration of individual running bouts represent measures of the hamster's motivation to run [5]. For instance, loss of body fat energizes food seeking behavior and increases the motivation for intracranial self-stimulation [19] and voluntary running [5] in hamsters and other rodents as reflected by an increase in the rate and total frequency of these behaviors. Conversely, increases in body fat or body size by means of forced intragastric administration of food [20] or by a variety of endocrine [5] and neurosurgical manipulations ([19] and Potter, Borer and Fileccia, unpublished data, 1981) reduce the motivation for intracranial self-stimulation and voluntary running as demonstrated by a reduction in the rate and total incidence of such behaviors.

Our data are consistent with the hypothesis that the stimulation of endogenous opiate receptors participates in the mediation of motivated running behavior. In particular, release of endogenous opiates and consequent stimulation of opiate receptors by voluntary running in hamsters may maintain and prolong this behavior. Facilitation of the speed of running and maintenance of longer running bouts may occur through the enhancement of incentive properties of this behavior by opiate receptor stimulation.

The apparent independence of hamster's hypothalamic self-stimulation behavior from endogenous opiate influence stands in contrast to the apparent opiate facilitation of this behavior in the rat [29]. This discrepancy may be a function of species difference in the role of opiates in the maintenance of self-stimulation behavior. More likely, the apparent independence of hamster self-stimulation behavior is the function of electrode placement. Even in the rat, self-stimulation rate is ten times more sensitive to the opiate receptor blockade in

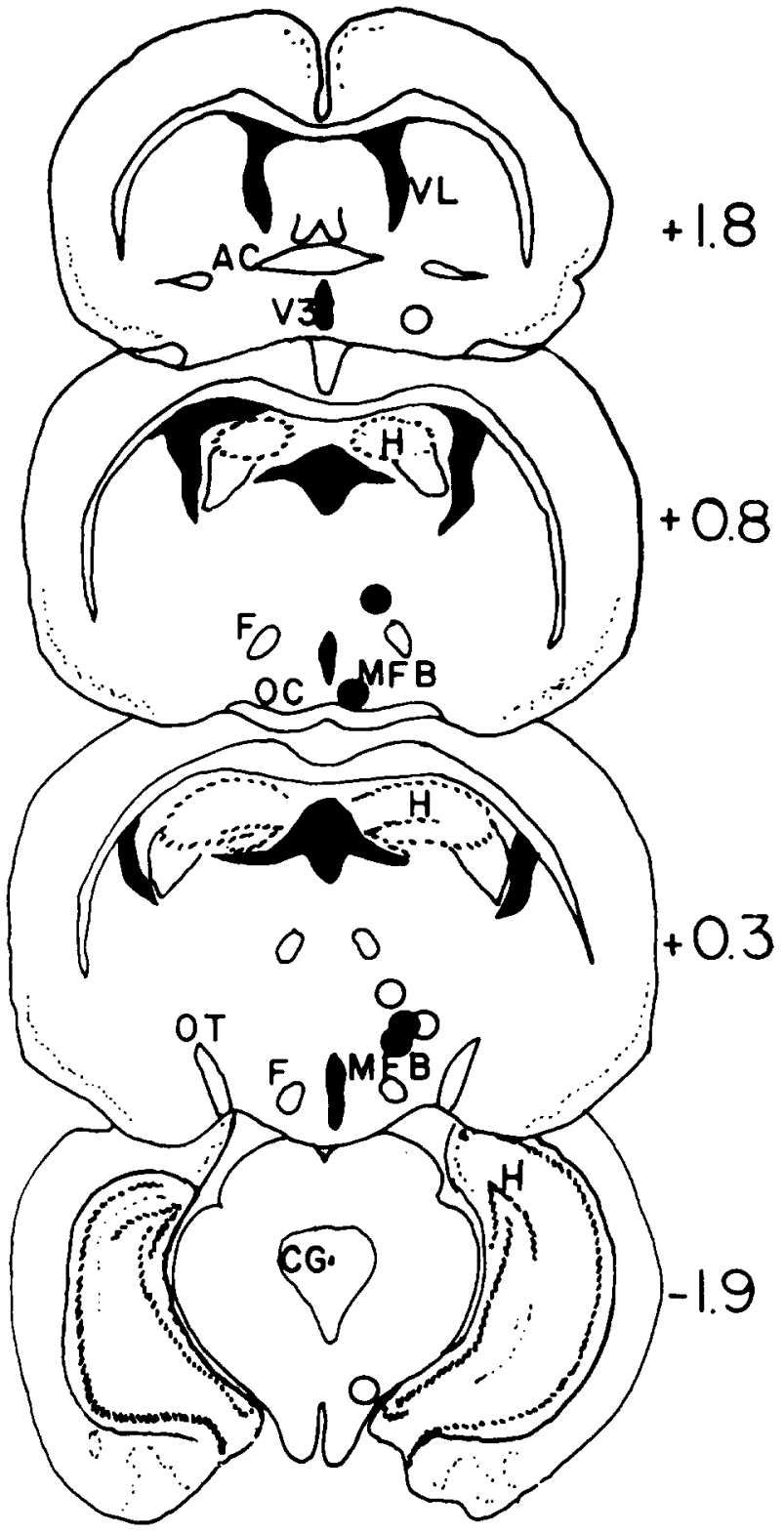

FIG. 3. Location of effective (solid circles) and ineffective (open circles) sites for tips of self-stimulation electrodes. Numbers, in $\mathrm{mm}$, denote the distance of coronal planes anterior $(+)$ or posterior $(-)$ with respect to bregma in brains positioned horizontally between bregma and lambda. Abbreviations: AC, anterior commisure; CG, central gray; $\mathrm{F}$, formix; $\mathrm{H}$, hippocampus; MFB, medial forebrain bundle; OC, optic chiasm; OT, optic tract; VL, lateral ventricle; V3, third ventricle.

the central gray area than in the MFB [29]. Thus, specific opiate facilitation of voluntary running and lack of such an effect on intracranial self-stimulation in hamsters may be an artifact of the location of electrode placement rather than a true difference in the biological role of opiate receptor stimulation in these two incentive behaviors.

The association of voluntary running in hamsters with opiate receptor stimulation as well as with increased release 
of growth hormone (GH) and acceleration of somatic growth [6] raises the question whether these two phenomena are causally related. Opiate receptor stimulation facilitates pituitary $\mathrm{GH}$ and prolactin release in rodents $[9,32,37]$ and may contribute to exercise-induced facilitation of $\mathrm{GH}$ secretion and of somatic growth in hamsters. Facilitation of GH secretion and of somatic growth by voluntary exercise in hamsters but not in rats or guinea-pigs [4] may thus reflect differences in the magnitude of exercise-induced opiate receptor stimulation in the three rodent species.

\section{ACKNOWLEDGEMENTS}

This research was supported, in part. by the National Science Foundation grants PCM78-07626 and PCM81-04375 to Katarina T. Borer. We thank A. A. Rubin, Endo Laboratories, Wilmington, DE for the gift of naltrexone $\mathrm{HCl}$.

\section{REFERENCES}

1. Belluzzi, J. D. and L. Stein. Enkephalin may mediate euphoria and drive-reduction reward. Nature 266: 556-558, 1977.

2. Berk, L. S., S. A. Tan, C. L. Anderson and G. Reiss $\beta$-Endorphin response to exercise in athletes and non-athletes. Med Sci Sports Exer 13: 134A, 1981.

3. Bonen, A., A. N. Belcastro. W. Y. Ling and A. A. Simpson. Profiles of selected hormones during menstrual cycles of teenage athletes. J Appl Phvsiol 50: 545-551, 1981.

4. Borer, K. T. Characteristics of growth-inducing exercise. Physiol Behav 24: 713-720, 1980.

5. Borer, K. T. The nonhomeostatic motivation to run in the golden hamster. In: Changing Concepts of the Nervous System. edited by A. R. Morrison and P. L. Strick. New York: Academic Press, 1982.

6. Borer, K. T. and R. P. Kelch. Increased serum growth hormone and somatic growth in exercising adult hamsters. Am J Physiol 234: E611-E616, 1978.

7. Borer, K. T., R. P. Kelch, M. P. White, L. Dolson and L. R. Kuhns. The role of the septal area in the neuroendocrine control of growth in the adult golden hamster. Neuroendocrinology' 23 133-150, 1977

8. Borer, K. T., J. B. Powers, S. S. Winans and E. S. Valenstein. Influence of olfactory bulb removal on ingestive behaviors, activity levels, and self-stimulation in hamsters. I Comp Physiol Psychol 86: 396-403, 1974.

9. Bruni, J. F.. D. A. Van Vugt, S. Marshall and J. Meites. Effects of naloxone, morphine and methionine enkephalin on serum prolactin, luteinizing hormone, follicle stimulating hormone, thyroid stimulating hormone, and growth hormone. Life $S_{c} i \mathbf{2 1}$ $461-466,1977$

10. Carr, D. B., B. A. Bullen. G. S. Shrinar, M. A. Arnold, M. Rosenblatt, I. Z. Beitins, J. B. Martin and J. W. McArthur. Physical conditioning facilitates the exercise-induced secretion of beta-endorphin and beta-lipotropin in women. $N$ Engl J Med 305: 560-562, 1981.

11. Chesher, G. B. and B. Chan. Footshock induced analgesia in mice: its reversal by naloxone and cross tolerance with morphine. Life Sci 21: 1569-1574, 1977.

12. Colt, E. W. D., S. L. Wardlaw and A. G. Frantz. The effect of running on plasma $\beta$-endorphin. Life $S c i$ 28: 1637-1640, 1981

13. Dale, E. D. H. Gerlach and A. L. Wilhite. Menstrual dysfunction in distance runners. Obstet Gynecol 54: 47-53, 1979.

14. Farrell, P. A., W. K. Cates and M. G. Maksud. Plasma $\beta$-endorphin/ $\beta$-lipotropin immunoreactivity increase after

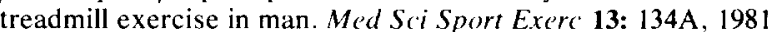

15. Feicht, C. B., T. S. Johnson, B. J. Martin, K. B. Spartes and W. W. Wagner, Secondary amenorrhea in athletes. Lanc'et 2: $1145-1146.1978$

16. Fraioli, F., C. Moretti, D. Paolucci, E. Alicicio, F. Crescenci and G. Fortinio. Physical exercise stimulates marked concomitant release of $\beta$-endorphin and adrenocorticotropic hormone $(\mathrm{ACTH})$ in peripheral blood in man. Experentia 36: $987-$ 989. 1980

17. Frisch. R. E., G. Wyshak and L. Vincent. Delayed menarche and anenorrhea in ballet dancers. $N$ Engl I Med 303: 17-19, 1980.

18. Gispen, W. H., V. M. Wiegant, A. F. Bradbury, E. C. Hulme, D. G. Smyth, C. R. Snell and D. de Wied. Induction of excessive grooming in the rat by fragments of lipotropin. Nature 264 $794-795,1976$
19. Hoebel, B. G. and P. Teitelbaum. Hy pothalamic control of feeding and self-stimulation. Science 135: 375-377, 1962.

20. Hoebel, B. G. and R. D. Thompson. Aversion to lateral hypothalamic stimulation caused by intragastric feeding or obesity. $J$ Comp Physiol Psychol 68: 536-543, 1969.

21. Katz, R. J. Identification of a novel class of central reward sites showing a delayed and cumulative response to opiate blockades. Pharamcol Biochem Behav 15: 131-134, 1981.

22. Katz, R. J. The temporal structure of reinforcement: an analysis of brain-stimulated reward. Behav Neural Biol. 26: 416-430, 1979.

23. Katz, R. J., B. J. Carroll and G. Baldrighi. Behavioral activation by enkephalins in mice. Pharmacol Biochem Behav 5: 691-695. 1976.

24. Katz, R. J. and J. Gelbart. Endogenous opiates and behavioral responses to environmental novelty. Behav Biol 24: 338-348, 1978.

25. Madden, J., H. Akil, R. L. Patrick and J. D. Barchas. Stressinduced parallel changes in central opioid levels and pain responsiveness in the rat. Nature 265: 358-360, 1977.

26. Malina. R. M., W. W. Spirduso, C. Tate and A. M. Baylor. Age at menarche and selected menstrual characteristics in athletes at different levels and in different sports. Med $S_{c}$ i Sports 10: 218 222,1978

27. McArthur, J. W. B. A. Bullen, I. Z. Beitins, M. Pagano, T. M. Badger and A. Klibanski. Hypothalamic anenorrhea in runners of normal body composition. Endocr Res Commun 7: 13-25. 1980 .

28. Morgan, W. P. and M. L. Pollock. Psychologic characterization of the elite distance runner. Ann NY Acad Sci 301: 382-403. 1977.

29. Schaefer. G. T. and R. P. Michael. Threshold differences for naloxone and naltrexone in the hypothalamus and midbrain using fixed ratio brain self-stimulation in rats. Psychopharmacology (Berlin) 74: 17-22, 1981.

30. Schultz, R., M. Wuster and A. Herz. Supersensitivity to opioids following the chronic blockade of endorphin action by naloxone. Naunyn Schmeidebergs Arch Pharmacol 306: 93-96. 1979.

31. Shainberg, D. Long distance running as meditation. $A / n n Y$ Acad Sci 301: 1002-1009, 1977.

32. Sharr, C. J., R. C. A. Frederickson, N. B. Dininger and L. Jackson. Enkephalin analogues and naloxone modulate the release of growth hormone and prolactin-evidence for regulation by an endogenous opiate peptide in the brain. Life Sci 21: 853$860,1977$.

33. Stein. L. and J. D. Belluzzi. Brain endorphins: possible role in reward and memory formation. Fed Proc 38: 2468-2472, 1979.

34. Stubbs, W. A., A. Jones, C. R. W. Edwards, G. Delitala, W. J. Jeffcoate, S. J. Rutter and G. M. Besser. Hormonal and metabolic responses to an enkephalin analogue in normal man. Lancet 1: 1225-1227, 1978.

35. Sutton, J. and L. Lazarus. Growth hormone in exercise: Comparison of physiological and pharmacological stimuli. I Appl Physiol 41: 523-527, 1976.

36. Tang, A. H. and R. J. Collins. Enhanced analgesic effects of morphine after chronic administration of naloxone in the rat. Eur J Pharmacol 47: 473-474, 1978.

37. Van Vugt, D. A. and J. Meites. Influence of endogenous opiates on anterior pituitary function. Fed Proc 39: 2533-2538. 1980. 
38. Walker, J. M., G. G. Berntson, T. S. Paolucci and T. C. Champrey. Blockade of endogenous opiates reduces activity in the rat. Pharmacol Biochem Behav 14: 113-116, 1981.

39. Wardlaw, S. L. and A. G. Frantz. Effect of swimming stress on brain $\beta$-endorphin and ACTH. Clin Res 28: 482A, 1980.
40. Warren, M. P. The effects of exercise on pubertal progression and reproductive function in girls. $J$ Clin Endocrinol Metab 51: $1150-1157,1980$.

41. Willer, J. C., H. Dehen and C. Cambier. Stress-induced analgesia in humans: Endogenous opioids and naloxonereversible depression of pain reflexes. Science 212: 689-690, 1981 . 